\title{
Keragaman Bakteri Endofit Penghasil L-Asparaginase Bebas L-Glutaminase
}

\section{Diversity of Endophytic Bacteria as a L-Asparaginase Producer Free of L-Glutaminase}

\author{
Tri Ratna Sulistiyani*, Dinihari Indah Kusumawati \\ Pusat Penelitian Biologi-LIPI, Cibinong, Indonesia \\ *E-mail: trilisty01@gmail.com
}

\begin{abstract}
Abstrak
Endofit merupakan mikroba potensial sumber penghasil senyawa aktif penting. Endofit yang diisolasi dari tanaman obat tropis telah menarik perhatian karena biodiversitasnya yang tinggi dan diperkirakan mampu menghasilkan senyawa baru di bidang kesehatan. L-asparaginase merupakan enzim pertama dengan aktivitas antileukemia yang sedang intensif dipelajari. Penelitian ini bertujuan untuk mengoleksi dan mengidentifikasi bakteri endofit dari tanaman obat tropis serta melakukan penapisan potensi penghasil enzim L-asparaginase bebas L-Glutaminase. Tanaman Gliricidia sepium, Pittosporum moluccanum, Clerodendrum buchanani, dan Zingiberaceae dikoleksi dari Desa Wanggameti, Sumba Timur, NTT. Sampel disterilkan menggunakan metode sterilisasi permukaan dan bakteri endofit diisolasi menggunakan metode plant piece pada media R2A. Bakteri endofit terisolasi diidentifikasi berdasarkan sekuen 16S rDNA. Penapisan bakteri endofit penghasil enzim Lasparaginase dilakukan secara kualitatif menggunakan media R2A termodifikasi dengan penambahan Lasparagin dan indikator phenol red. Terdapat 34 isolat bakteri endofit berhasil diisolasi dari 5 sampel tanaman obat. Sebanyak 14 genus terdiri dari 17 spesies bakteri yang berbeda diperoleh dari 34 isolat terseleksi. Bakteri endofit Pseudomonas stutzeri strain SMKL1 dan Rhizobium radiobacter strain SMKW2 dari tanaman Kahili berpotensi sebagai penghasil L-asparaginase bebas L-glutaminase dan bepeluang sebagai kandidat penghasil senyawa kemoterapi kanker leukemia.
\end{abstract}

Kata kunci: Bakteri endofit; L-asparaginase; Tanaman obat

\begin{abstract}
Endophytes are potential as a source of active compound producer. Endophytes that is isolated from tropical medicinal plants has been getting attention due to its high biodiversity and active compound producing ability. L-asparaginase is the first enzyme used as chemotherapeutic agent for leukemia. The aim of this study is to collect the endophytic bacteria associated with tropical medicinal plants from Sumba Island and investigate the activity of L-asparaginase free L-Glutaminase from endophytic bacteria isolates. The samples Gliricidia sepium, Pittosporum moluccanum, Clerodendrum buchanani, and Zingiberaceae are collected from Wanggameti, East Sumba, NTT. Samples are sterilized using surface-sterilization method and endophytic bacteria are isolated using plant piece method on R2A media. Selected endophytic bacteria are identified by $16 S$ rDNA sequences. L-asparaginase screening is conducted using modified $R 2 A$ with addition of L-asparagine and phenol red as colour indicator. A total of 34 isolates of endophytic bacteria were collected from 5 samples. A total of 14 genus consisted of 17 different bacterial species were obtained from 34 selected isolates. Endophytic bacteria of P. stutzeri strains of SMKL1 and R. radiobacter strains of SMKW2 from the Kahili plant were needed as L-glutaminase-free L-asparaginase and were potential to be candidate of leukemia cancer chemotherapy.
\end{abstract}

Keywords: Endophytic bacteria; L-asparaginase; Medicinal plants 


\section{PENDAHULUAN}

Kebutuhan senyawa obat kanker untuk kemoterapi semakin meningkat seiring meningkatnya angka kejadian 36 jenis kanker di 185 negara yang mencapai 18.1 juta kasus dan 9.6 juta kematian. ${ }^{1}$ Kanker menempati peringkat ke-7 sebagai penyebab kematian utama di Indonesia dengan persentase kematian $5.7 \%$ dari total angka kejadian dengan tingkat prevalensi 4.3 per 1000 populasi. $^{2}$ Obat-obatan dari tanaman herbal telah lama digunakan oleh masyarakat untuk mengobati berbagai penyakit seperti diabetes, kanker, dan masalah kulit. Beberapa tanaman yang dapat digunakan untuk terapi kanker diantaranya Tapak dara (Catharanthus roseus), Kemangi (Ocimum sanctum), Lidah buaya (Aloe vera), Ginseng India (Withania somnifera), Bawang putih (Allivum sativum), Kunyit (Curcuma longa $)^{3}$, Taxus brevifolia, dan beberapa tanaman obat lainnya. Senyawa kurkuminoid yang terkandung dalam tanaman kelompok famili Zingiberaceae mempunyai banyak manfaat salah satunya sebagai antikanker. ${ }^{4}$

Selama beberapa dekade pengobatan kanker dilakukan dengan kemoterapi, operasi dan radiasi, atau kombinasi dari ketiganya. ${ }^{5}$ Akan tetapi, penggunaan obat melalui kemoterapi secara konvensional sering kali tidak efisien dan memiliki kendala dalam pengiriman obat ke target sel kanker sehingga kemoterapi justru membahayakan sel-sel sehat pasien. Perkembangan kemoterapi saat ini semakin pesat untuk meningkatkan efisiensi obat ke sel kanker dan meminimalisir pengaruh obat ke sel sehat menggunakan Drug Delivery System (DDS) yang dikombinasikan dengan nanopartikel yang berfungsi sebagai molekul pembawa obat ke sel kanker. ${ }^{6}$

Pengetahuan tentang etnobotani suatu tanaman mampu memberikan informasi yang cukup untuk melakukan isolasi senyawa aktif dari tanaman tradisional. Keterbatasan sediaan tanaman di alam dianggap sebagai faktor pembatas untuk memperoleh senyawa aktif baru. Bakteri endofit merupakan salah satu mikroba sumber senyawa bioaktif potensial. Bakteri endofit hidup mengolonisasi pada tanaman terutama daun, batang, akar, dan dapat tinggal untuk seluruh atau sebagian dari siklus hidupnya tanpa menyebabkan kerusakan atau penyakit bagi inangnya. Populasi dan profil bakteri endofit pada tanaman dipengaruhi oleh beberapa faktor yaitu kondisi lingkungan tempat tumbuh tanaman inang, jenis tanaman, umur tanaman, dan umumnya tanaman dengan sejarah etnobotani tinggi memiliki prospek keragaman mikroba endofit yang tinggi pula. $^{7-9}$

Endofit saat ini dipandang sebagai sumber potensial untuk menghasilkan metabolit sekunder dan enzim penting dalam industri. Senyawa alami berupa enzim yang berasal dari mikroba dimanfaatkan oleh industri farmasi sebagai obat, contohnya L-asparaginase, kitinase, kolagenase, lipase, nattokinase, L-amino acid $\alpha$-ligase, dan serratiopeptidase. ${ }^{10,11}$ Enzim L-asparaginase merupakan enzim yang rutin digunakan dalam kemoterapi terutama untuk kanker sel darah putih. ${ }^{12,13}$ Enzim akan mengambil asam amino esensial asparagin dari sel kanker dan memecahnya sehingga sel kanker mengalami kelaparan dan akhirnya mati. Enzim tersebut bertanggung jawab dalam konversi L-asparagin menjadi L-aspartat dan amonia. L-asparaginase dari bakteri yang telah digunakan adalah Elspar ${ }^{\circledR}$ dari Escherichia coli dan Erwinase $^{\circledR}$ dari Erwinia chrysantemi. ${ }^{9}$ Selain dalam bidang kesehatan, L-asparaginase juga digunakan dalam membantu proses reduksi kadar Lasparagin yang merupakan prekursor utama dalam pembentukan kontaminasi makanan akrilamid. Bakteri endofit yang berasal dari lima tanaman obat Catharanthus roseus, Ocimum sanctum, Aloe vera, Withania somnifera, dan Marrayo konengi memiliki aktivitas Lasparaginase yang dapat dikembangkan sebagai senyawa antikanker baru. ${ }^{10}$ 
Beberapa mikroba dapat menghasilkan L-asparaginase dan memiliki aktivitas Lglutaminase karena L-asparagin dan Lglutamin memiliki struktur yang sama. Mikroba tersebut antara lain Serratia marcescens, E. coli, E. chrysantemi, Pseudomonas sp. dan Acinetobacter glutaminasificans. Studi melaporkan bahwa adanya aktivitas L-glutaminase dapat menyebabkan efek samping selama terapi antara lain alergi, pankreatitis, diabetes, dan kelainan koagulasi. ${ }^{11}$

Secara tradisional tanaman obat yang digunakan untuk isolasi bakteri endofit memiliki sifat antimikroba, namun belum ada data ilmiah yang mempelajari sifat antikankernya. Oleh karena itu, penapisan mikroba penghasil L-asparaginase bebas L-glutaminase perlu dilakukan dari berbagai sumber, terutama dari bakteri endofit. Penelitian ini bertujuan untuk mengisolasi, mengidentifikasi, dan melakukan penapisan bakteri endofit penghasil enzim L-asparaginase bebas Lglutaminase dari tanaman obat yang dikoleksi dari Desa Wanggameti, Sumba Timur, Nusa Tenggara Timur (NTT).

\section{METODE}

Penelitian ini merupakan percobaan laboratorium yang dilakukan di Laboratorium Biosistematika dan Kultur Koleksi Mikroba, Pusat Penelitian BiologiLIPI.

\section{Alat dan bahan}

Alat yang digunakan antara lain mesin PCR (Thermo Scientific), Elektroforator (Takara, model Mupid-EXu), dan UV transilluminator (Biorad). Bahan kimia yang digunakan adalah etanol $70 \%$. natrium hipoklorit 3\%, sikloheksamida (Merck), media R2A (Difco), $\mathrm{KOH}$ (Merck), gliserol (Merck), GoTaq Green Master Mix 2x (Promega), primer 27F dan 1492R (IDT), DMSO for molecular (Sigma), agarosa (Thermo Scientific), etidium bromida (Biotech), pati terlarut (Merck), $\quad \mathrm{K}_{2} \mathrm{HPO}_{4} \quad$ (Merck), $\quad \mathrm{MgSO}_{4}$ (Merck), agar (Difco), phenol red (Sigma), L-asparagin (Merck), L-glutamin (Merck).

\section{Sampel tanaman}

Sampel tanaman obat diambil dari Desa Wanggameti, Sumba Timur, NTT dari ketinggian yang berbeda pada tahun 2016 . Tanaman terpilih adalah tanaman sehat bebas kontaminasi patogen tanaman. Sampel yang digunakan sebanyak lima tanaman obat (Tabel 1). Sampel tanaman diidentifikasi di Herbarium Bogoriense, Pusat Penelitian Biologi-LIPI berdasarkan karakteristik morfologi.

\section{Penyiapan sampel tanaman}

$\begin{array}{cccr}\text { Sampel tanaman } & \text { dari lokasi } \\ \text { pengambilan } & \text { sampel } & \text { dibawa ke }\end{array}$
laboratorium untuk diisolasi bakteri endofitnya. Sampel tanaman (rimpang, batang, daun, bunga, dan buah) dicuci dengan air mengalir selama 5-10 menit, dipotong-potong, dan dilanjutkan dengan proses sterilisasi permukaan.

\section{Sterilisasi permukaan jaringan tanaman}

Sampel tanaman direndam dalam etanol $70 \%$ selama 3 menit, lalu direndam dengan natrium hipoklorit $3 \%$ selama 5 menit, dan dibilas dengan etanol $70 \%$ selama 30 detik, dilanjutkan pencucian dengan akuades steril selama 2 menit.

Tabel 1. Tanaman obat yang diambil dari Sumba Timur

\begin{tabular}{ccc}
\hline Kode sampel & Nama Tanaman & $\begin{array}{c}\text { Manfaat tanaman } \\
\text { (secara tradisional) }\end{array}$ \\
\hline SMG & Gamal (Gliricidia sepium) & Pengawet mayat \\
SMK & Kahili (Pittosporum moluccanum) & Obat luka kulit \\
SMR & Rarawala (Clerodendrum buchanani) & Obat sakit kepala \\
SMKz & Zingiberaceae & Imunostimulan \\
SMZg & Zingiberaceae & Antimikroba \\
\hline
\end{tabular}


Pencucian dengan akuades steril diulang sebanyak tiga kali. ${ }^{12}$ Sampel kemudian dikeringkan menggunakan kertas tisu steril. Efisiensi sterilisasi permukaan diuji dengan menyebar $100 \mu \mathrm{L}$ akuades hasil pencucian terakhir pada beberapa jenis media yang ditambah sikloheksamida $50 \mu \mathrm{g} / \mathrm{mL}$ untuk menghambat pertumbuhan cendawan. Media yang digunakan adalah R2A dengan konsentrasi 1/10. Akuades hasil pencucian yang menunjukkan adanya pertumbuhan mikroba tidak digunakan sebagai sampel isolasi bakteri endofit.

\section{Isolasi bakteri endofit}

Isolasi bakteri endofit dilakukan dengan metode plant piece. ${ }^{13}$ Sampel tanaman yang telah steril dipotong menjadi ukuran 4-6 mm. Sampel kemudian diletakkan di atas media yang telah ditambah sikloheksamida $50 \mu \mathrm{g} / \mathrm{mL}$. Cawan petri selanjutnya diinkubasi selama 2-15 hari pada suhu $28{ }^{\circ} \mathrm{C}$. Bakteri yang tumbuh dari metode plant piece diisolasi dan dipurifikasi. Bakteri endofit yang memiliki karakteristik morfologi berbeda dipilih untuk digunakan pada tahap berikutnya. Karakteristik fenotip yang diamati antara lain adalah warna, tepian permukaan, serta reaksi Gram menggunakan uji $\mathrm{KOH}^{14}$

\section{Pemurnian bakteri endofit}

Koloni bakteri yang telah tumbuh dimurnikan pada media Nutrient Agar (NA) dengan cara digores berdasarkan metode kuadran. Pemurnian dilakukan sampai diperoleh koloni tunggal. Koloni yang telah murni kemudian ditanam dalam tabung reaksi yang berisi agar miring NA dan disimpan pada suhu $4{ }^{\circ} \mathrm{C}$. Isolat murni selanjutnya dipelihara dengan baik dan disimpan dalam gliserol $10 \%$ pada suhu $80{ }^{\circ} \mathrm{C} .{ }^{14}$

\section{Ekstraksi DNA, amplifikasi PCR, dan elektroforesis}

Sel dari koloni tunggal pada permukaan media padat diambil menggunakan tusuk gigi steril dan disuspensikan ke dalam 20 $\mu \mathrm{L}$ air bebas nuklease. Suspensi kemudian di-vortex selama 10 detik dan diinkubasi pada suhu $98{ }^{\circ} \mathrm{C}$ selama 5 menit. Supernatan dipisahkan dari endapan dengan sentrifugasi untuk selanjutnya digunakan sebagai cetakan DNA.

DNA diamplifikasi menggunakan GoTaq Green Master Mix 2x dengan sepasang primer universal 27F (5'AGAGTTTGATCCTGGCTCAG-3') dan 1492R (5'-GTTACCTTGTTACGACTT3'). Setiap tabung berisi Ultrapure water 9,75 $\mu \mathrm{L}$, GoTaq Green Master Mix 2x 12,5 $\mu \mathrm{L}$, primer $27 \mathrm{~F}(10 \mu \mathrm{M}) 0,625 \mu \mathrm{L}$, primer 1492R $(10 \mu \mathrm{M}) 0,625 \mu \mathrm{L}$, DMSO $0,5 \mu \mathrm{L}$, dan $1 \mu \mathrm{L}$ sampel DNA dengan total volume $25 \mu \mathrm{L}$. Amplifikasi dilakukan pada kondisi PCR: predenaturasi $95{ }^{\circ} \mathrm{C}$ selama 90 detik, dilanjutkan 30 siklus terdiri atas denaturasi $\left(95^{\circ} \mathrm{C}, 30\right.$ detik), annealing (50 ${ }^{\circ} \mathrm{C}, 30$ detik), elongasi $\left(72{ }^{\circ} \mathrm{C}, 90\right.$ detik), dan final extension pada $72{ }^{\circ} \mathrm{C}$ selama 5 menit, dilanjutkan $4{ }^{\circ} \mathrm{C}$ selama 20 menit. Hasil amplifikasi dielektroforesis pada gel agarosa $1 \%$. Setelah selesai, gel direndam dalam larutan etidium bromida $5 \mu \mathrm{g} / \mathrm{mL}$ selama 30 menit. Hasil elektroforesis dilihat menggunakan alat UV transilluminator. ${ }^{15,16}$

\section{Sekuensing 16S rDNA dan analisis bioinformatika}

Hasil amplifikasi PCR disekuensing di Laboratorium Macrogen Korea menggunakan automated DNA sequencer (ABI PRISM 3130 Genetic Analyzer) (Applied Biosystems). Data hasil sekuensing diolah dengan program Bioedit. Homologi sekuen 16S rDNA dicari pada server Eztaxon. Sekuen referensi diperoleh dari bank data GenBank/DDBJ/EMBL yang diakses secara online melalui internet www.ezbiocloud.net. Analisis pohon filogenetik menggunakan metode neighbour-joining yang terimplementasi dalam MEGA 7.0 dengan nilai bootstrap 1000x. ${ }^{17-20}$ 


\section{Penapisan bakteri endofit dalam menghasilkan $\mathbf{L}$-asparaginase atau $\mathbf{L}$ - glutaminase}

Penapisan kemampuan bakteri endofit dalam menghasilkan L-asparaginase atau L-glutaminase menggunakan metode uji lempeng cepat berdasarkan kemampuan membentuk warna merah muda di sekitar koloni yang ditumbuhkan pada media R2A termodifikasi. Komposisi media R2A termodifikasi adalah dextrose $0.5 \mathrm{~g}$, pati terlarut $0.5 \mathrm{~g}, \mathrm{~K}_{2} \mathrm{HPO}_{4} 0.3 \mathrm{~g}, \mathrm{MgSO}_{4} 0.05$ g, Agar $16 \mathrm{~g}$, akuades $1000 \mathrm{~mL}$. Media ditambah dengan phenol red $0.009 \%$, dan asam amino (L-asparagin $5 \mathrm{~g}$ atau Lglutamin $5 \mathrm{~g}$ ) dengan $\mathrm{pH}$ 6.2. Isolat bakteri selanjutnya digores pada permukaan media R2A termodifikasi dan diinkubasi pada suhu $30{ }^{\circ} \mathrm{C}$ selama $24-48$ jam. Isolat bakteri juga ditumbuhkan di media R2A termodifikasi tanpa asam amino (Lasparagin atau L-glutamin) sebagai kontrol negatif. $^{21}$

\section{HASIL DAN PEMBAHASAN}

\section{Isolasi bakteri endofit dari tanaman obat}

Isolasi bakteri endofit asal tanaman obat dengan metode sterilisasi permukaan berhasil mensterilkan permukaan sampel. Hal ini ditunjukkan dengan tidak ditemukan mikroba yang tumbuh pada cawan petri yang telah disebar dengan akuades cucian terakhir hasil proses sterilisasi permukaan. Hasil isolasi menunjukkan bahwa bakteri endofit ditemukan pada semua bagian tanaman mulai dari rimpang, batang, daun, bunga, dan buah. Bakteri endofit ditemukan hampir pada semua bagian tanaman inang termasuk akar atau rimpang, batang, daun, biji, buah, umbi, dan juga dalam nodul tanaman legum. ${ }^{22}$

Bakteri yang keluar dari bagian tanaman sampel dianggap sebagai bakteri endofit. Bakteri yang terisolasi dari lima jenis tanaman sampel menunjukkan jumlah yang bervariasi (Gambar 1). Jumlah terbanyak diperoleh dari sampel tanaman obat Kahili (SMK) sebanyak 11 isolat. Terdapat dua faktor umum yang berpengaruh terhadap kelimpahan dan distribusi bakteri endofit pada suatu tanaman yaitu musim dan usia tanaman dimana tanaman yang lebih tua mempunyai organ yang lebih besar sehingga diperkirakan jumlah endofit akan lebih banyak. $^{23,24}$ Beberapa faktor lain yang berpengaruh adalah rotasi tanaman, kondisi tanah, jaringan tanaman, dan keberadaan patogen tanaman. Jumlah endofit pada tanaman obat paling banyak terdapat pada bagian daun, diikuti batang, dan akar. ${ }^{24}$

Daun pada umumnya dipilih oleh endofit karena permukaannya yang luas, kaya nutrisi, dan dinding selnya tipis sehingga memudahkan kolonisasi endofit. Hal tersebut berbeda dengan hasil studi yang menunjukkan bahwa jumlah bakteri endofit terisolasi lebih banyak dikoleksi dari bagian batang. Hal ini disebabkan batang merupakan tempat menyalurkan sari makanan dari daun menuju seluruh bagian tanaman.

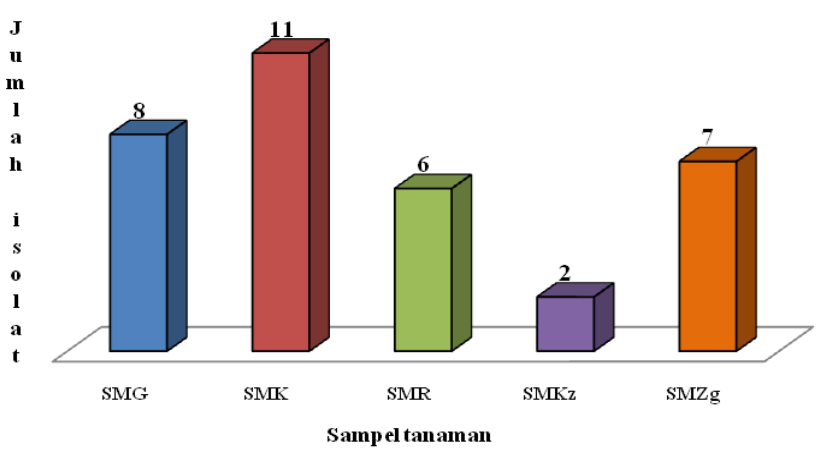

Gambar 1. Bakteri endofit terisolasi dari tanaman obat di Sumba Timur ((Gamal (SMG); Kahili (SMK); Rarawala (SMR); Zingiberaceae (SMKz); Zingiberaceae (SMZg)).

Sebanyak 34 isolat bakteri endofit berhasil diisolasi dari 5 sampel tanaman obat yang diteliti. Isolat bakteri endofit yang berasosiasi dengan tanaman obat dari 
Sumba Timur menunjukkan karakteristik yang beragam. Sebagian besar isolat memiliki karakteristik Gram negatif, bentuk circular, tepian entire, permukaan shiny, tidak tembus pandang, dan berwarna putih dan kuning. Hasil uji $\mathrm{KOH}$ menunjukkan 85,29\% merupakan bakteri Gram negatif dan $14,71 \%$ bakteri Gram positif (Tabel 2). Hasil pewarnaan Gram menunjukkan semua isolat memiliki sel berbentuk batang.

Tabel 2. Identitas bakteri endofit dari tanaman obat berdasarkan sekuen 16S rDNA

\begin{tabular}{|c|c|c|c|c|}
\hline Isolat & Uji KOH & Identitas terdekat & Kesamaan (\%) & Filum \\
\hline SMGW1 & - & Chryseobacterium pallidum DSM 18015(T) & 99,42 & Bacteroidetes \\
\hline SMGW2 & - & Pantoea eucrina PSNIH & 99,70 & Gammaproteobacteria \\
\hline SMGW3 & - & Pantoea anthophila LMG2558(T) & 99,81 & Gammaproteobacteria \\
\hline SMGW4 & - & Chryseobacterium pallidum DSM 18015(T) & 99,42 & Bacteroidetes \\
\hline SMGW5 & + & Curtobacterium oceanosedimentum ATCC 31317(T) & 99,48 & Actinobacteria \\
\hline SMGW6 & - & Sphingobium yanoikuyae ATCC 51230 (T) & 99,69 & Alphaproteobacteria \\
\hline SMGW7 & - & Rhizobium radiobacter ATCC 19358(T) & 99,69 & Alphaproteobacteria \\
\hline SMGW8 & - & Sphingobium yanoikuyaeATCC $51230(\mathrm{~T})$ & 99,62 & Alphaproteobacteria \\
\hline SMKL1 & - & Pseudomonas stutzeriATCC 17588(T) & 99,86 & Gammaproteobacteria \\
\hline SMKL2 & - & Sphingobium yanoikuyae ATCC 51230 (T) & 99,62 & Alphaproteobacteria \\
\hline SMKL3 & + & Sphingobium yanoikuyae ATCC 51230 (T) & 99,70 & Alphaproteobacteria \\
\hline SMKL4 & - & Curtobacterium oceanosedimentum ATCC 31317(T) & 99,48 & Actinobacteria \\
\hline SMKL5 & - & Cupriavidus metallidurans $\mathrm{CH} 34(\mathrm{~T})$ & 98,98 & Betaproteobacteria \\
\hline SMKW1 & - & Curtobacterium oceanosedimentum ATCC 31317(T) & 99,93 & Actinobacteria \\
\hline SMKW2 & - & Rhizobium radiobacter ATCC 19358(T) & 99,51 & Alphaproteobacteria \\
\hline SMKW3 & - & Sphingobium yanoikuyae ATCC 51230(T) & 99,69 & Alphaproteobacteria \\
\hline SMKW4 & - & Sphingobium yanoikuyae ATCC 51230(T) & 99,70 & Alphaproteobacteria \\
\hline SMKW5 & - & Methylobacterium oryzae CBMB20(T) & 99,91 & Alphaproteobacteria \\
\hline SMKFr1 & + & Curtobacterium oceanosedimentum & 99,70 & Actinobacteria \\
\hline SMRW1 & - & Xanthomonas cynarae CFBP 4188(T) & 99,93 & Gammaproteobacteria \\
\hline SMRW2 & - & Enterobacter tabaci YIM Hb-3(T) & 99,88 & Gammaproteobacteria \\
\hline SMRW3 & - & Enterobacter tabaci YIM Hb-3(T) & 99,69 & Gammaproteobacteria \\
\hline SMRFr1 & - & Xanthomonas cynarae CFBP $4188(\mathrm{~T})$ & 99,93 & Gammaproteobacteria \\
\hline SMRFl1 & - & Enterobacter tabaci YIM Hb-3(T) & 99,81 & Gammaproteobacteria \\
\hline SMRF12 & - & Xanthomonas cynarae CFBP 4188(T) & 99,93 & Gammaproteobacteria \\
\hline SMKzR1 & - & Stenotrophomonas panacihumi JCM 16536(T) & 96,94 & Gammaproteobacteria \\
\hline SMKzR2 & - & Enterobacter tabaci YIM Hb-3(T) & 99,90 & Gammaproteobacteria \\
\hline SMZgR1 & - & Enterobacter tabaci YIM Hb-3(T) & 99,89 & Gammaproteobacteria \\
\hline SMZgR2 & - & Enterobacter asburiae & 99,89 & Gammaproteobacteria \\
\hline SMZgR3 & - & Ancylobacter sonchi $\operatorname{Osot}(\mathrm{T})$ & 99,62 & Alphaproteobacteria \\
\hline SMZgFl1 & - & Rhizobium radiobacter ATCC 19358(T) & 98,25 & Alphaproteobacteria \\
\hline $\mathrm{SMZgFl} 2$ & + & Pseudomonas entomophila L48(T) & 99,78 & Gammaproteobacteria \\
\hline $\mathrm{SMZgFl3}$ & - & Bacillus mobilis 0711P9-1(T) & 100,00 & Firmicutes \\
\hline SMZgFl4 & - & Variovorax gossypiiJM-310(T) & 99,85 & Betaproteobacteria \\
\hline
\end{tabular}

Ket: (+) bakteri Gram positif; (-) bakteri Gram negatif 


$\begin{array}{ll}\begin{array}{l}\text { Identifikasi bakteri endofit dari } \\ \text { tanaman obat }\end{array} & \begin{array}{l}\text { Tingkat keragaman bakteri endofit yang } \\ \text { berasal dari tanaman yang dikoleksi dari }\end{array} \\ \text { Analisis sekuen 16S rDNA isolat } & \begin{array}{l}\text { Sumba Timur juga sangat tinggi yaitu dari } \\ \text { bakteri endofit yang dilakukan secara }\end{array} \\ \text { parsial dan perbandingan dengan sekuen } & \text { genus yang merepresentasikan 17 spesies } \\ \text { tipe bakteri lain di bank data DNA, } & \begin{array}{l}\text { yang berbeda seperti yang ditampilkan } \\ \text { pada Tabel } 2 .\end{array}\end{array}$
tinggi dengan data base yaitu 98\%-100\%.

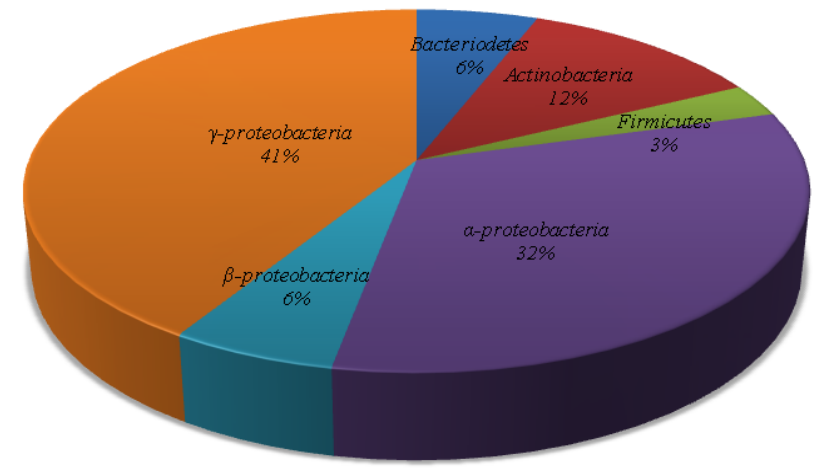

\section{Gambar 2. Komposisi bakteri endofit yang berasosiasi dengan tanaman obat asal Sumba Timur}

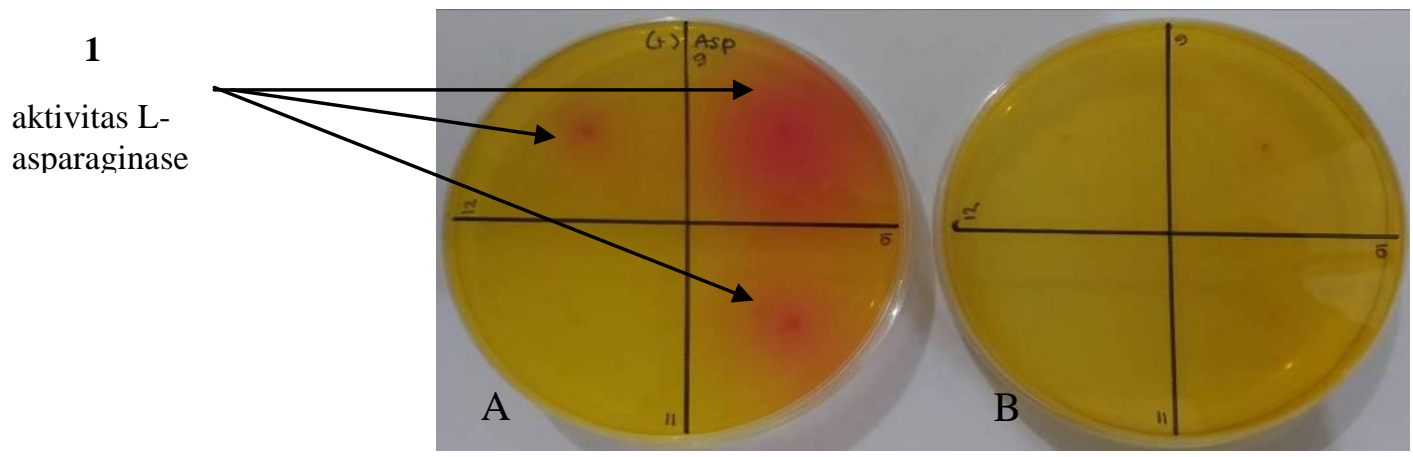

2

aktivitas Lglutaminase
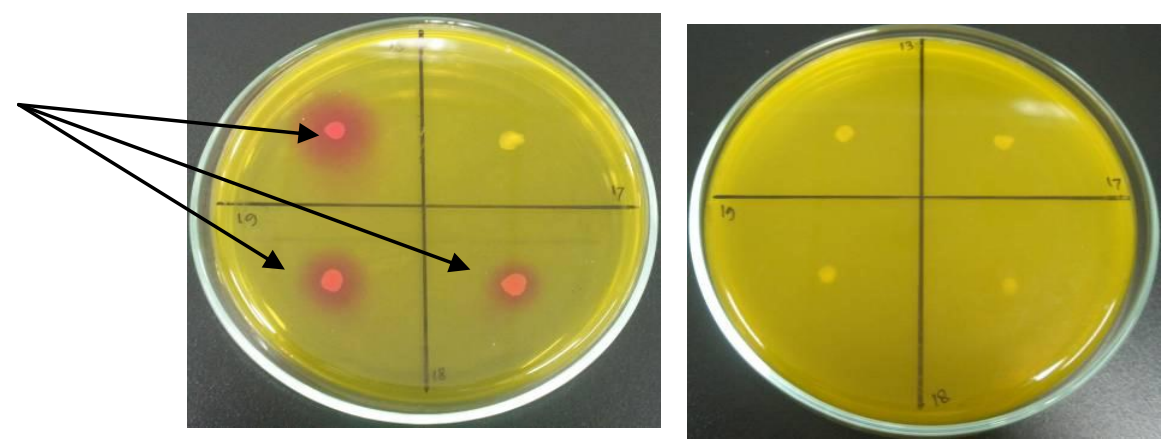

Gambar 3. (1) Deteksi produksi L-asparaginase (2) Deteksi produksi L-glutaminase dari bakteri endofit yang berasosiasi dengan tanaman obat dari Sumba Timur (A: media dengan L-asparaginase/L-glutamin; B: media tanpa L-asparagin/L-glutamin, kontrol negatif) 
Sebanyak 34 isolat terisolasi terdiri dari 4 filum antara lain Actinobacteria, Firmicutes, Bacteroidetes, dan Proteobacteria dengan isolat paling dominan adalah filum Proteobacteria yang terdiri dari kelompok $\gamma$-proteobacteria, $\alpha$ proteobacteria, dan $\beta$-proteobacteria (Gambar 2). Hal ini sejalan dengan studi Chowdhury et al. yang menyatakan bahwa Proteobacteria dominan pada tanaman gingseng dari Korea. ${ }^{25}$ Studi ini menunjukkan bahwa isolat Firmicutes merupakan filum dengan isolat terkecil dengan satu isolat yang teridentifikasi sebagai Bacillus yaitu Bacillus mobilis. Hal tersebut berbeda dengan hasil studi lain yang menyatakan bahwa bakteri endofit genus Bacillus dan Pseudomonas lebih banyak terisolasi dibandingkan dengan genus lainnya. ${ }^{25}$ Studi ini mengambil sampel tanaman obat dari lingkungan dengan temperatur dan ketinggian yang berbeda, dimana hal tersebut memengaruhi populasi dan profil bakteri endofit pada tanaman. ${ }^{26,27}$

\section{Penapisan bakteri endofit penghasil L- asparaginase dan L-glutaminase}

Hasil penapisan awal menunjukkan beberapa isolat bakteri endofit berpotensi menghasilkan L-asparaginase. Hal ini ditandai dengan terbentuknya warna merah muda disekeliling isolat bakteri pada media R2A termodifikasi dengan penambahan senyawa L-asparagin. Berdasarkan reaksi kimia yang terjadi pada L-asparagin, adanya L-asparaginase yang dihasilkan oleh bakteri endofit menyebabkan terbentuknya L-aspartat dan amonia. Indikator phenol red pada kondisi asam berwarna kuning, sedangkan pada kondisi basa akan berwarna merah muda.

Amonia yang dihasilkan dari reaksi Lasparaginase bersifat basa dan kondisi ini akan mengubah warna media menjadi merah muda (Gambar 3). Warna media akan tetap kuning pada isolat yang tidak memiliki kemampuan menghasilkan Lasparaginase. \begin{tabular}{lrr}
\multicolumn{1}{c}{ Aktivitas } & L-glutaminase & selama \\
produksi & L-asparaginase & dapat \\
menyebabkan efek samping selama & terapi \\
secara enzimatis. ${ }^{11} \quad$ Beberapa & isolat \\
penghasil & L-asparaginase & juga \\
menghasilkan & L-glutaminase & yang
\end{tabular} ditunjukkan dengan terbentuknya warna merah muda pada media dengan penambahan L-glutamin (Gambar 3).

Tabel 3 menunjukkan aktivitas Lasparaginase dari 23 isolat. Kemampuan isolat bakteri dalam menghasilkan Lasparaginase berbeda-beda berdasarkan besar kecilnya zona merah muda yang terbentuk. Hasil uji kualitatif produksi Lasparaginase menunjukkan 12 dari 23 isolat memiliki aktivitas L-asparaginase yang tinggi. Bakteri potensial penghasil Lasparaginase adalah kelompok Enterobacteriaceae contohnya $E$. coli dan E. chrysanthemi. ${ }^{28}$ Hal ini sesuai dengan hasil penapisan bahwa bakteri dengan aktivitas L-asparaginase sebagian besar dari kelompok Enterobacteriaceae yaitu genus Pantoea dan Enterobacter (Tabel 3).

Tabel 3 menunjukkan 4 isolat dari 23 isolat memiliki aktivitas L-asparaginase dan tidak menunjukkan aktivitas Lglutaminase. Hasil penapisan menunjukkan bahwa $P$. stutzeri strain SMKL1 dan $R$. radiobacter strain SMKW2 memiliki aktivitas Lasparaginase yang tinggi dan tidak memiliki aktivitas L-glutaminase sehingga berpotensi sebagai kandidat penghasil senyawa agen kemoterapi kanker leukemia. $P$. eucrina dan $R$. radiobacter strain SMZgFl1 meskipun tidak memiliki aktivitas L-glutaminase tetapi aktvitas Lasparaginase yang rendah sehingga tidak potensial sebagai kandidat penghasil senyawa agen kemoterapi kanker leukemia.

Analisis filogenetik bakteri endofit penghasil L-asparaginase bebas Lglutaminase menggunakan isolat-isolat strain type yang diambil secara online dari List of Procaryotic names with Standing in Nomenclature LPSN (Gambar 4). ${ }^{29}$ Empat bakteri endofit terseleksi berdasarkan 
analisis filogenetik termasuk dalam filum Proteobacteria yaitu Gammaproteobacteria dan Alphaproteobacteria. Isolat SMKL1 yang teridentifikasi sebagai $P$. stutzeri termasuk dalam genus Pseudomonas, ordo Pseudomonadales, Kelas Gammaproteobacteria. Isolat
SMGW2 teridentifikasi sebagai $P$. eucrina genus Pantoea, ordo Enterobacteriales, Kelas Gammaproteo-bacteria, sedangkan isolat SMKW2 dan SMZgFl1 teridentifikasi sebagai $R$. radiobacter termasuk dalam genum Rhizobium, Ordo Rhizobiales, Kelas Alphaproteobacteria.

Tabel 3. Penapisan bakteri endofit penghasil L-asparaginase dan L-glutaminase yang berasosiasi dengan tanaman obat

\begin{tabular}{|c|c|c|c|c|}
\hline $\begin{array}{l}\text { Kode } \\
\text { isolat }\end{array}$ & Identitas & Famili & $\begin{array}{c}\text { Aktivitas L- } \\
\text { asparaginase }\end{array}$ & $\begin{array}{l}\text { Aktivitas L- } \\
\text { glutaminase }\end{array}$ \\
\hline SMGW2 & Pantoea eucrina PSNIH1 & Enterobacteriaceae & + & - \\
\hline SMGW3 & Pantoea anthophila LMG2558(T) & Enterobacteriaceae & +++ & + \\
\hline SMRW2 & Enterobacter tabaci YIM Hb-3(T) & Enterobacteriaceae & +++ & + \\
\hline SMRW3 & Enterobacter tabaci YIM Hb-3(T) & Enterobacteriaceae & +++ & + \\
\hline SMRF11 & Enterobacter tabaci YIM Hb-3(T) & Enterobacteriaceae & +++ & + \\
\hline SMKzR2 & Enterobactertabaci $\mathrm{YIM} \mathrm{Hb}-3(\mathrm{~T})$ & Enterobacteriaceae & +++ & ++ \\
\hline SMZgR1 & Enterobacter tabaci YIM Hb-3(T) & Enterobacteriaceae & +++ & + \\
\hline $\mathrm{SMZgR2}$ & Enterobacter asburiae & Enterobacteriaceae & +++ & + \\
\hline SMGW6 & Sphingobium yanoikuyae ATCC 51230 (T) & Sphingomonadaceae & + & ++ \\
\hline SMGW8 & Sphingobium yanoikuyae ATCC 51230 (T) & Sphingomonadaceae & ++ & + \\
\hline SMKL2 & Sphingobium yanoikuyae ATCC 51230 (T) & Sphingomonadaceae & ++ & + \\
\hline SMKW3 & Sphingobium yanoikuyae ATCC 51230(T) & Sphingomonadaceae & ++ & ++ \\
\hline SMKW4 & Sphingobium yanoikuyae ATCC 51230(T) & Sphingomonadaceae & ++ & ++ \\
\hline SMGW7 & Rhizobium radiobacter ATCC 19358(T) & Rhizobiaceae & +++ & ++ \\
\hline SMKW2 & Rhizobium radiobacter ATCC 19358(T) & Rhizobiaceae & +++ & - \\
\hline SMZgFl1 & Rhizobium radiobacter ATCC 19358(T) & Rhizobiaceae & + & - \\
\hline SMKL1 & Pseudomonas stutzeri ATCC 17588(T) & Pseudomonadaceae & +++ & - \\
\hline SMKL4 & Curtobacterium oceanosedimentum ATCC 31317(T) & Microbacteriaceae & + & + \\
\hline SMKL5 & Cupriavidus metallidurans $\mathrm{CH} 34(\mathrm{~T})$ & Burkholderiaceae & +++ & +++ \\
\hline SMKW5 & Methylobacterium oryzae CBMB20(T) & Methylobacteriaceae & + & + \\
\hline SMKzR1 & Stenotrophomonas panacihumi JCM 16536(T) & Xanthomonadaceae & + & +++ \\
\hline SMZgFl4 & Variovorax gossypii JM-310(T) & Comamonadaceae & +++ & ++ \\
\hline $\mathrm{SMZgFl3}$ & Bacillus mobilis 0711P9-1(T) & Bacillaceae & ++ & + \\
\hline
\end{tabular}

Ket: (+++) aktivitas tinggi; (++) aktivitas sedang; (+) aktivitas rendah; (-) tidak ada aktivitas 


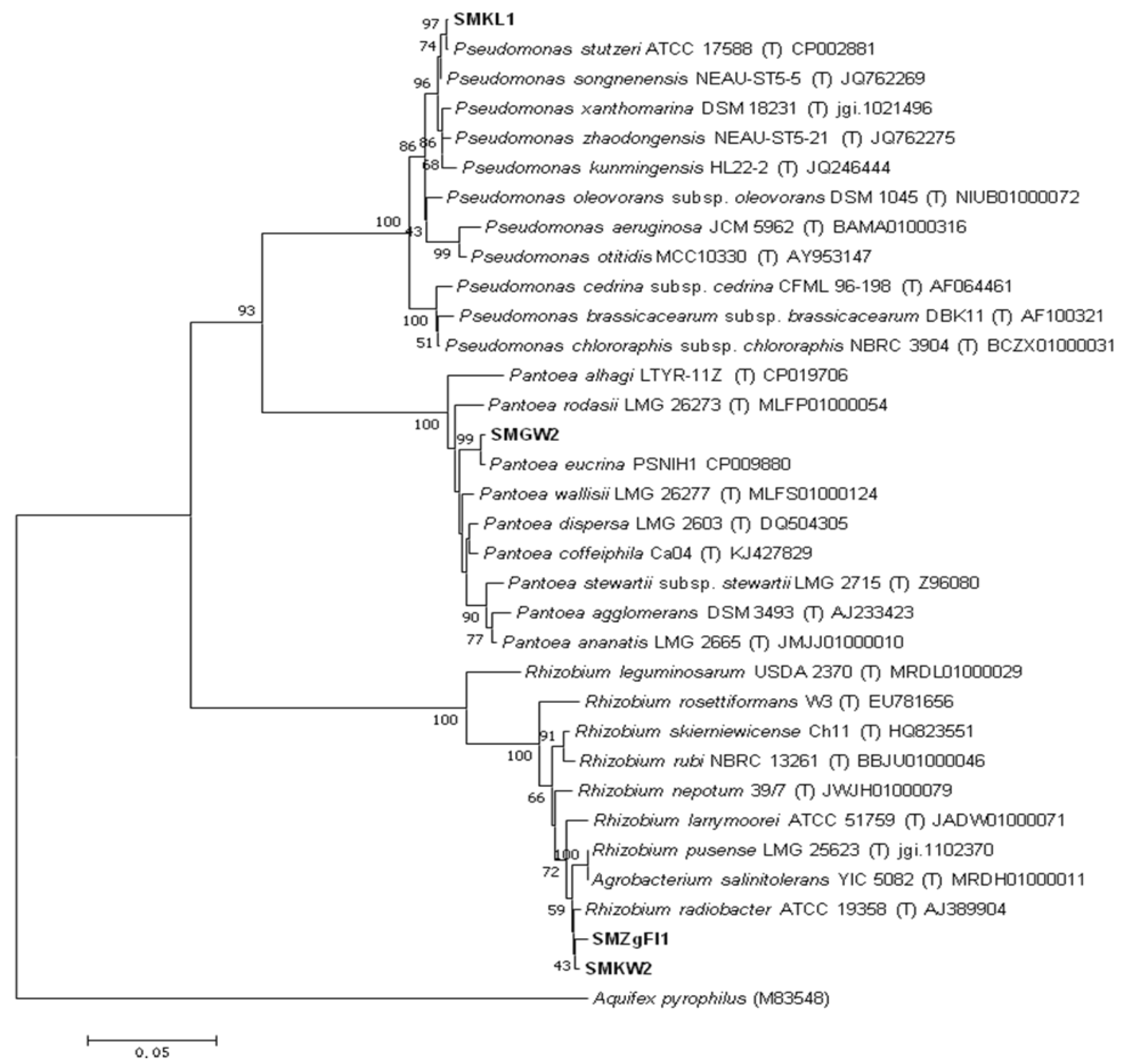

Gambar 4. Pohon filogenetik berdasar sekuen 16S rDNA dari bakteri endofit penghasil Lasparaginase tanpa aktivitas L-glutaminase menggunakan metode neighbour-joining, model K2 dan distribusi Gamma dengan nilai bootstarp 1000 replikasi

\section{KESIMPULAN}

Bakteri endofit yang berasosiasi dengan tanaman obat G. sepium, $P$. moluccanum, C. buchanani, dan Zingiberaceae, memiliki tingkat keragaman bakteri yang sangat tinggi. Bakteri endofit $P$. stutzeri strain SMKL1 dan $R$. radiobacter strain SMKW2 dari tanaman Kahili berpotensi sebagai penghasil L-asparaginase bebas Lglutaminase dan hal ini diharapkan menjadi peluang bakteri endofit tersebut sebagai kandidat penghasil senyawa kemoterapi kanker leukemia.

\section{UCAPAN TERIMA KASIH}

Penelitian ini didanai oleh Proyek DIPA Pusat Penelitian Biologi - Lembaga Ilmu Pengetahuan Indonesia (LIPI) TA 2016. Penulis mengucapkan terima kasih kepada Sdri. Rinatu Siswi S.Si atas bantuannya selama melakukan penelitian di laboratorium

\section{DAFTAR RUJUKAN}

1. Bray F, Ferlay J, Soerjomataram I. Global Cancer Statistics 2018: GLOBOCAN Estimates of Incidence and Mortality 
Worldwide for 36 Cancers in 185 Countries. 2018;394-424.

2. Wahidin M, Noviani R, Hermawan S, Andriani V, Ardian A, Djarir $\mathrm{H}$. Population-Based Cancer Registration in Indonesia. 2012;13:1709-10.

3. Dixit S, Ali H. Anticancer activity of Medicinal plant extract-A review. J Chem Cheml Sci. 2010;1(1):79-85.

4. Suhirman S, Hernani, Syukur C. Uji toksisitas ekstrak lempuyang gajah (Zingiber zerumbet) terhadap larva udang (Artemia salina Leach.) Bul Littro. 2006;XVII(1):30-8.

5. Devita VT, Chu E. AACR Centennial Series A History of Cancer Chemotherapy. 2008;(21):8643-54.

6. Hu Q, Sun W, Wang C, Gu Z. Recent advances of cocktail chemotherapy by combination drug delivery systems. Adv Drug Deliv Rev 2015; Available from: http://dx.doi.org/10.1016/j.addr.2015.10.0 22

7. Tan RX, Zou WX. Endophytes: a rich source of functional metabolites. Nat Prod Rep. 2001;18(4):448-59.

8. Vellard M. The enzyme as drug: Application of enzymes as pharmaceuticals. Curr Opin Biotechnol. 2003;14(4):444-50.

9. Manasa C, Nalini MS. L-Asparaginase Activity of Fungal Endophytes from Tabernaemontana heyneana Wall. (Apocynaceae), Endemic to the Western Ghats (India). Int Sch Res Not. 2014;2014:1-7.

10. Joshi RD, Kulkarni NS. Optimization studies on L-asparaginase production from endophytic Bacteria. 2016;2:624-9.

11. Saxena A, Upadhyay R, Kango N. Isolation and identification of actinomycetes for production of novel extracellular glutaminase free Lasparaginase. Indian $\mathrm{J}$ Exp Biol. 2015;53(12):786-93.

12. Jalgaonwala RE, Mahajan RT. Evaluation of hydrolytic enzyme activities of endophytes from. Biotechnol Adv. 2011;7(6):1733-41.

13. Arau WL, Marcon J, Maccheroni W, Elsas JD Van, Vuurde JWL Van. Diversity of Endophytic Bacterial Populations and Their Interaction. 2002;68(10):4906-14.

14. Powers EM. Efficacy of the Ryu nonstaining $\mathrm{KOH}$ technique for rapidly determining gram reactions of food-borne and waterborne bacteria and yeasts. Appl Environ Microbiol. 1995;61(10):3756-8.

15. Packeiser H, Lim C, Balagurunathan B, $\mathrm{Wu}$ J, Zhao H. An extremely simple and effective colony PCR procedure for bacteria, yeasts, and microalgae. Appl Biochem Biotechnol. 2013;169(2):695700.

16. Palaniappan $\mathrm{P}$, Chauhan PS, Saravanan VS, Anandham R, Sa T. Isolation and characterization of plant growth promoting endophytic bacterial isolates from root nodule of Lespedeza sp. Biol Fertil Soils. 2010;46(8):807-16.

17. Hall TA. BioEdit: a user-friendly biological sequence alignment editor and analysis program fro Windows 95/98/NT. Nucleic Acids Symp Series. 1999;41:9598

18. Kim OS, Cho YJ, Lee K, Yoon SH, Kim $\mathrm{M}, \mathrm{Na} \mathrm{H}$, et al. Introducing EzTaxon-e: A prokaryotic 16s rRNA gene sequence database with phylotypes that represent uncultured species. Int $\mathbf{J}$ Syst Evol Microbiol. 2012;62(PART 3):716-21.

19. Saitou N, Nei M. The neighbour-joining method: a new method for reconstructing phylogenetic trees. Mol Biol Evo. 1987;4:406-25.

20. Kumar S, Stecher G, Tamura K. MEGA7: Molecular Evolutionary Genetics Analysis Version 7 . 0 for Bigger Datasets. 2018;33(7):1870-4.

21. Mahajan R V., Saran S, Saxena RK, Srivastava AK. A rapid, efficient and sensitive plate assay for detection and screening of 1-asparaginase-producing microorganisms. FEMS Microbiol Lett. 2013;341(2):122-6.

22. Ruby EJ. A Review: Bacterial Endophytes and their Bioprospecting. Journal of Pharmacy Research, 2011;4(3), pp.795-799.

23. Chareprasert S, Piapukiew J, Thienhirun S, Whalley AJS, Sihanonth P, Products F. Endophytic fungi of teak leaves Tectona grandis L . and rain tree leaves Samanea. 2006;481-2.

24. Chow Y, Ting ASY. Endophytic 1asparaginase-producing fungi from plants associated with anticancer properties. J Adv Res. 2015;6(6):869-76.

25. Chowdhury EK, Jeon J, Rim SO, Park Y. 
Composition, diversity and bioactivity of culturable bacterial endophytes in mountain-cultivated ginseng in Korea. Sci Rep. 2017;(July):1-10. Available from: http://dx.doi.org/10.1038/s41598-01710280-7

26. Hardoim PR, Overbeek LS Van, Berg G, Pirttilä M, Compant S, Campisano A, et al. The Hidden World within Plants: Ecological and Evolutionary Considerations for Defining Functioning of Microbial Endophytes. 2015;79(3):293-320.

27. Ratna Sulistiyani T, Lisdiyanti P, Lestari Y. Population and Diversity of Endophytic Bacteria Associated with
Medicinal Plant Curcuma zedoaria. Microbiol Indones. 2014;8(2):65-72. Available from: http://jurnal.permi.or.id/index.php/mionli ne/article/view/276

28. Lopes AM, Oliveira-Nascimento L de, Ribeiro A, Tairum CA, Breyer CA, Oliveira MA de, et al. Therapeutic 1asparaginase: upstream, downstream and beyond. Crit Rev Biotechnol. 2017;37(1):82-99.

29. Parte AC, Road W. LPSN - list of prokaryotic names with standing in nomenclature. 2014;42(November 